\title{
Akut Apandisit ile Karışan Brusella Epididimorşiti; Bir Olgu Sunumu
}

\section{Brusella Epididymo-Orchitis Confused with Acute Appendicitis; A Case Report}

Adem Bayraktar ${ }^{1}$,

Yusuf Doğan²,

Mehmet Reşat Ceylan ${ }^{3}$,

İbrahim Koç4,

Alper Aytekin ${ }^{5}$

${ }^{1}$ Istanbul Üniversitesi Istanbul Tıp Fakültesi Genel Cerrahi Ana Bilim Dalı, Istanbul,

Türkiye

${ }^{2}$ Viranşehir Devlet Hastanesi, Mikrobiyoloji Bölümü, Sanlıurfa, Türkiye

${ }^{3}$ Viranşehir Devlet Hastanesi, Enfeksiyon

Hastalıkları Bölümü, Şanlıurfa, Türkiye

${ }^{4}$ Viranşehir Devlet Hastanesi, Göğüs

Hastalıkları Bölümü, Şanlıurfa, Türkiye

${ }^{5}$ Viranşehir Devlet Hastanesi, Genel Cerrahi

Bölümü, Şanlıurfa, Türkiye

Geliş Tarihi/Received: 11 Şubat 2017

Kabul Tarihi/Accepted: 04 Ağustos 2017

Yazıșma Adresi: Adem Bayraktar, İstanbul

Üniversitesi İstanbul Tıp Fakültesi Genel Cerrahi Ana Bilim Dalı, İstanbul, Türkiye

e-posta: dradem61@gmail.com

\begin{abstract}
$\ddot{O z}$
Bruselloz, pastorize edilmemiş süt ve süt ürünleri ile bulaşan bir zoonozdur. En sık gastrointestinal sistemi tutmakla birlikte daha az sıklıkta genito-üriner sistemi de tutmaktadır. Brusellozun en sık görülen genitoüriner komplikasyonu ise brusella epididimoorşitidir. Bu yazıda sadece sağ alt kadran ağrısı ile gelen hastanın yapılan ilk fizik muayenesinde akut apandisit ön tanısı düşünülürken, tetkik ve bulgular sonucunda öyküsünün derinleştirilmesiyle bruselloza bağlı olarak gelişen unilateral epididimoorşit olgusu irdelenmiş ve olgunun klinik ve laboratuvar bulguları sunulmuştur. Brucellozun endemik olduğu ülkemizde, özellikle akut batının eşlik ettiği ama bunu görüntüleme yöntemlerinin onaylamadığı durumlarda bruselloz akla getirilmelidir

Anahtar Kelimeler: Akut batın, epididimoorşit, bruselloz.

\section{Abstract}

Brusellosis is a zoonotic disease which is transmitted with nonpasteurized milk and milk products. Mostly effects the gastrointestinal system and less the genitourinary system. Most common genitourinary complication of brucellosis is epididymo-orchitis. Here we present a case which presented with right lower quadrant pain in which physical examination lead us to the preliminary diagnosis of appendicitis after laboratuary results, cilinical findings and deepining the history the patient was diagnosed with unilateral epididimoorchit and here presented with clinical laboratuary findings. Brusellosis which is endemic in our country, should be kept in mind especially when accompanied with acute abdomen eventhoug imaging prosedures do not confirm the diagnosis.
\end{abstract}

Keywords: Acute abdomen, epididymo-orchitis, brusellosis

ORCID

Adem Bayraktar

https://orcid.org/0000-0002-0463-6335

\section{GíRiş}

Bruselloz dünyanın çeşitli bölgelerinde endemik görülen ve büyük ekonomik kayıplara neden olan zoonotik bir hastalıktır. Hayvanların kontrol altında olmadığı özellikle gelişmekte olan ülkelerde milyonlarca insan bruselloz açısından risk altındadır. Genellikle enfekte hayvanın sekresyonlarının bütünlüğü bozulmuş deri ile direkt teması, çiğ süt ve süt ürünlerinin kullanımı, enfekte aerosollerin inhalasyonu ve konjunktival temas ile bulaşmaktadır. Türkiye gibi hastalığın endemik olduğu ülkelerde bulaş sıklıkla çiğ süt ürünlerinin tüketimiyle olmaktadır $(1,2)$.

Hastalık ortalama olarak 2-3 hafta süren kuluçka döneminden sonra ondüle seyreden ateş, özellikle geceleri olan terleme, eklem ağrıları, iştahsızlık, bitkinlik, halsizlik, kilo kaybı, baş ağrısı gibi nonspesifik belirtilerle ortaya çıkar. Bruselloz, tüm sistemleri etkileyip farklı klinik tablolarla ortaya çıkabilen, tanı ve tedavisinde güçlükler yaşanan bir hastalıktır. Tanı, klinik bulgularla birlikte etkenin izolasyonu ve serolojik testler ile konulmaktadır. Bakteriyemi sırasında bakteriler birçok organa yerleşerek bazı atipik formlarda karşımıza çıkabilir. Bunlar arasında gastrointestinal sistem, kas iskelet sistemi, santral sinir sistemi ve genitoüriner sistem tutulumları ön sıralarda yer alır. Brusellozda, genitoüriner tutulum \%2-14 oranındadır. Erkeklerde en sık tek taraflı epididimoorşit ile kendini gösterir (3-6). Erken tanı konulamayan ve ampirik tedavi uygulanan hastalarda yapılması gereken etkene yönelik tedavinin ertelenmesi, nekrotizan orşit ve infertilite gibi ciddi

Atıf yapmak için: Bayraktar A, Doğan Y, Ceylan MR, Koç I, Aytekin A. Akut Apandisit ile Karışan Brusellaepididimorşiti; Bir Olgu Sunumu. Selcuk Med J 2019;35(1): 47-50 
komplikasyonlara yol açabilmektedir $(7,8)$.

\section{OLGU}

34 yaşında erkek hasta, iki gündür devam eden karın ağrısı şikayeti ile genel cerrahi polikliniğine başvurdu. Batın muayenesinde sağ alt kadranda hassasiyet ve McBurney (+) idi. Hikayesinde karın ağrısının ataklar halinde olduğu öğrenildi. Hemogramında beyaz küre sayısı 9320/mm³ ${ }^{3}$ CRP $12,3 \mathrm{mg} / \mathrm{dl}$ idi. Tam idrar tetkiki normaldi. Acil batın ultrasonagrafisinde özellik saptanmayan hastanın çekilen bilgisayarlı batın tomografisinde apendiks normal boyutlarda ve şüpheli sağ inguinal herni görüntüsü mevcut idi. Hasta sağ inguinal herni şüphesiyle tekrar muayene edildiğinde sağ testisin kızarık, ödemli ve palpasyonla ağrılı olduğu görüldü. Yapılan skrotal USG'de sağ testis boyutunda artma $(10 \times 8 \mathrm{~cm}$ ) ve parankiminde $26,7 \times 17,2 \mathrm{~mm}$ boyutunda fokal orşit alanı ile uyumlu düzensiz sınırlı hipoekojen lezyon izlendi. Hasta üroloji bölümü ile konsülte edildi. Sağ epididimoorşit nedeni ile ayaktan antibiyoterapi ile takip önerildi. Epididimorşit tanısı alan ve akut appandisit muayene bulguları olan hasta müşahede amaçlı genel cerrahi servisine yatırıldı. Hastanın yatışından sonra takiplerinde $39.5^{\circ} \mathrm{C}$ 'ye varan ateş ve titreme şikayetleri oldu ve epididimoorşite bağlandı. Daha sonra ilerleyen saatlerde belinde ve bacaklarında şiddetli ağrı şikayetleri başladı. Hastanın anamnezi derinleştirildiğinde yaklaşık bir aydır olan eklem ağrısı, aralıklı olan ateşleri ve özellikle geceleri olan terleme şikayetlerinin olduğu öğrenildi. Öyküsünde hayvancılıkla uğraştığı ve taze peynir tükettiği öğrenilen hastada brusella orşitinden şüphelenildi. Yapılan Rose Bengal (RB) testi pozitif ve brucella tüp aglütinasyon (STA)testi 1/640 olarak tespit edildi. Kan kültüründe Brucellaspp. üremedi. Hastaya Streptomisin 1 g/gün, Rifampisin 600 mg/ gün ve doksisiklin $200 \mathrm{mg} / \mathrm{gün}$ başlandı. Akut batın bulguları kaybolan ve tedavinin 3 . gününde ateşi gerileyen hastanın, testisindeki ödemin ikinci haftada gerilediği görüldü. Streptomisin tedavisi 14 güne tamamlandı. Dört hafta sonra şikayetlerinin tamamı düzeldi. Tedavisi 8 haftaya tamamlanan hastanın tamamen iyileştiği görüldü ve takiplerinde herhangi bir sorunla karşılaşılmadı.

\section{TARTIŞMA}

Bruselloz klasik olarak titreme ile yükselen aleş, aşırı terleme, baş ağrısı, kırıklık, halsizlik, kilo kaybı, bel ağrısı ve yaygın vücut ağrıları ile kendini gösteren bir infeksiyon hastalığıdır. Tüm bu genel belirtilere ek olarak her hastada değişebilen farklı klinik tablolar gösterebilir.

Bruselloz vakalarında en sık rastlanan bulgular ateş, hepatomegali, sple nomegali, lenfadenomegali ve artrittir. Bruselloz, sıklıkla hayvancılıkla uğraşanlarda meslek hastalığı olarak görülmekle beraber özellikle gelişmekte olan ülkelerde toplumun her kesimini etkileyebilmektedir. Türkiye'nin çeşitli bölgelerinde bruselloz endemiktir ve çeşitli tarihlerde yapılan araştırmalarda seropozitiflik \%2-6 olarak belirlenmiştir. Ülkemizde 15-35 yaş grubunda daha sık olmak üzere her yaş ve cinsiyette görülebilmektedir. Pastörize edilmemiş, az pişmiş süt ve süt ürünlerinin tüketimi, enfekte hayvana veya doğum materyaline direkt temas başlıca bulaşma yollarıdır $(2,9)$. Gürsoy et al. (10) takip ettikleri 140 brusellozlu hastanın \%62.1'inde taze süt ve peynir tüketimi, \%49.3'ünde hayvan teması öyküsü saptamışlardır. Diğer bir çalışmada 26 brusella epididimoorşit (BEO) olgusu incelenmiş \%38'inde çiğ süt ve süt ürünleri tüketimi, \%4'ünde ise laboratuvar kazası tespit edilmiştir (4). Bizim hastamızda hayvancılıkla uğraştığı ve çiğ süt ve süt ürünleri tüketim öyküsü mevcuttu.

Bruselloz serileri incelendiğinde, en sık semptomların ateş yüksekliği (\%61.2-93), halsizlik (\%76-97.5), terleme (\%70.9-91) ve artralji (\%57-65) olduğu; hepatomegali (\%8.6-34.5), splenomegali (\%10.7-25.5), lenfadenopati (\%7-11.4) ve artritin (\%5.7-40) ise en sık görülen bulgular olduğu gözlenmiştir $(2,6,11)$. Brusellozda asıl dikkatin çekilmesi gereken nokta, bakterinin tüm organ ve sistemleri tutabilmesi nedeniyle çok çeşitli klinik tablonun ortaya çıkabileceğidir. Bunların başında $\% 70$ sıklıkla gastrointestinal sistem tutulumu gelmektedir. Literatürde bruselloza bağlı kolesistit, peritonit, pankreatit, mezenterlenfadenit sonucu akut batın gelişen olgular bildirilmiştir (12-14). Turhan et al. splenomegali ile birlikte olan; Bodur et al. $(12,15)$ ise mezenterik lenfadenit sunucu akut batın tablosu gelişen bruselloz olgusu bildirmişlerdir. Fernandez et al. (16) ateş, göbekten başlayan ve sağ alt kadrana lokalize olan karın ağrısı nedeniyle apendektomi yapılan 15 yaşında bir brusellozlu olgu sunmuşlardır. Kaya et al. (13) da benzer şekilde akut batın kliniğiyle seyreden iki bruselloz olgusu sunmuşlardır. Bizim olgumuzda yapılan ilk fizik muayenede sağ alt kadranda hassasiyet ve McBurney pozitif idi. Skrotal bir yakınması yoktu. Bu nedenle hastalığın endemik olduğu ülkemizde, özellikle akut batının eşlik ettiği ama bunu görüntüleme yöntemlerinin onaylamadığı durumlarda bruselloz akla getirilmelidir. 
Brusella enfeksiyonunun genitoüriner sistem tutulum sıklığı \%2-14 arasındadır. Bu sistemde en sık komplikasyonu genellikle tek taraflı seyreden epididimorşittir $(3,4)$. Akıncı et al. (17) çalışmasında Türkiye'deki brusella epididimorşit insidansı \%212,7 olarak rapor edilmiştir. Orşit tablosuyla gelen hastaların standart ampirik tedaviye cevap vermemeleri nedeniyle ya da zaman zaman tümör ön tanısı ile opere edildiği bildirilmektedir (1,17202). Antibiyoterapi ile düzelebilen bir tablo olması nedeniyle cerrahi girişim öncesinde epidemiyolojik öykü sorgulanarak hastaların bruselloz yönünden incelenmeleri gerekliliği açıktır. Ultrasonografinin BEO tanısında ve hastalığa yaklaşımda faydası olmakla birlikte, asıl kullanım alanı daha çok klinik tanıyı desteklemek üzere testiküler apse, torsiyon ve testis tümörünün ayırıcı tanısı olmaktadır (21). Bizde yapılan ultrasonografi sonuçları da yukarıda bahsettiğimiz gibi olup detaylı bir öykü, fizik muayene ve laboratuvar sonuçları doğrultusunda brusella epididimorşiti düşünülerek hastamıza antibiyoterapi uygulandı. Turunç et al. (7) yaptıkları çalışmada 152 epididimorşitli hasta incelemiş ve bunların \%8.6'sında brusella epididimoorşiti saptamışlardır. Colmenero k. gelişmekte olan ülkelerde doktorların brusellozu çok iyi bilmediklerini, bundan dolayı tanı ve tedavi gecikmelerinin meydana geldiğini ve bu gecikmelerin komplikasyonları anlamlı derecede arttırdığını bildirmişlerdir (22).

Bruselloz tanısı esas olarak hikaye, fizik muayene, klinik bulgular, aglütinasyon testi ve kan kültürüyle konmaktadır $(2,4,22)$. Sağlık Bakanlığı tarafından belirlenen vaka tanımına göre de klinik olarak uyumlu bulunan olgularda RB testi pozitifliği olası vaka, klinik olarak uyumlu, tedavi almamış vakalarda tek serum örneğinde Wright aglütinasyon testi (STA) ile antikor titresinin>1/160 veya en az 2 hafta ara ile alınmış çift serum örneğinde STA titresinin $\geq 4$ kat artış saptanması kesin vaka olarak tanımlanmıştır $(23,24)$. Kan kültürünün sensitivitesi yaklaşık $\% 50$ civarındadır ve yaklaşık olarak 1-3 haftada sonuçlanmaktadır (22). Olgumuzda kan kültürü negatif ve brusella aglütinasyon titresi ise 1/640 da pozitif bulunmuştur.

Tablonun çeşitliliği nedeniyle ülkemizde özellikle brusellozun endemik olduğu bölgelerde her hastanın değerlendirilmesi sırasında bruselloz yönünden epidemiyolojik öykünün sorgulanması, akut batının ve epididimoorşitin eşlik ettiği her durumda gerekli incelemelerin yapılması, erken ve doğru tanı açısından yararlı olacaktır.
Çıkar Çatışması: Çalışmada herhangi bir çıkar çatışması yoktur.

Finansal Çıkar Çatışması: Çalışmada herhangi bir finansal çıkar çatışması yoktur.

Yazışma Adresi: Adem Bayraktar, Istanbul Üniversitesi İstanbul Tıp Fakültesi Genel Cerrahi Ana Bilim Dalı, 34093 Istanbul, Türkiye

Cep Telefon: 05056870826 e-mail: dradem61@gmail.com

\section{KAYNAKLAR}

1. Akkurt A, Amasyalı AS, Kazan E, et al. Focal presentation of brucellosis; Epididymoorchiti a case report and review of the literature. The cystoscope 2014;1:58-62.

2. Topaktaş R, Ersöz C, Polat EC, et al. Brucella repididymoorchitis: A case report. J Clin Exp Invest 2012;3(1):117-20.

3. Young EJ. Brucellaspecies. In: Mandell GL, Dolin R, Bennett JE, eds. Mandell, Douglas, and Bennett's principles and practice of infectious diseases. 6th ed. Philadelphia: Churchill Livingstone 2005;2669-74.

4. Memish ZA, Venkatesh S. Brucella repididy moorchitis in saudi arabia: A retrospective study of 26 cases and review of literature. BJU. International 2001;88(1):72-6.

5. Polat K, Demirbaş M, Güler C, et al. Brusella epididimoorşiti olgu sunumu. Med J Kocatepe 2004;5(3):87-9.

6. Ural O, Dikici N. Brucella epididimoorşiti: Beş olgu sunumu. Klimik Dergisi 2010;23(1):22-5.

7. Turunç $T$, Kuzgunbay B, Turunç $T$. Epididimoorşit nedeniyle başvuran her hastada rutin brusella aglütinasyon testi istenmeli mi? Van Tıp Dergisi 2010;17(4):136-9.

8. Navarro-Martínez A, Solera J, Corredoira J, et al. Epididymoorchitis due to brucellamelitensis: A retrospective study of 59 patients. Clin Infect Dis 2001;33:2017-22.

9. Sözen TH. Bruselloz: Topçu AW, Söyletir G, Doğanay M eds. İnfeksiyon hastalıkları, 2. baskı Nobel Tıp Kitabevleri, İstanbul 2002;636-42.

10. Gürsoy B, Tekin-Koruk S, Sırmatel F, et al. Bruselloz: 140 olgunun değerlendirilmesi. Klimik Derg 2008;21(3):101-4.

11. Corbel MJ, Elberg SS, Cosivi O, eds. Brucellosis in humans and animals. Geneva: World Health Organization 2006.

12. Turhan V, Diktaş $H$, Öncül $O$. Akut karın ve pansitopeni tablosu ile seyreden bruselloz: Bir olgu sunumu. Klinik Dergisi 2008;21(1):31-3.

13. Kaya A, Akıl M, Temel H, et al. Akut batın kliniği ile seyreden brusella: İki olgu sunumu. Van Tıp Dergisi 2013;20(2):81-3.

14. Cesur S, Çapar Y, Demir P, et al. Brusellozlu 104 olgunun retrospektif olarak incelenmesi. İnfeksiyon Dergisi 2004;18:169-73.

15. Bodur $\mathrm{H}$, Çolpan A, Erbay A, et al. Akut batın tablosunu taklit eden bruselloz olgusu. Klinik Dergisi 2003;16(1):41-2.

16. Fernández MD, García JL, García FD, et al. Brucella acute abdomen mimicking appendicitis. Am J Med 2000;108(7):599600.

17. Akıncı $E$, Bodur $H$, Cevik MA, et al. A complication of brucellosis: Epididymoorchitis. Int J Infect Dis 2006;10:1717.

18. Yüce A, Alp-Çavuş S. Türkiye'de bruselloz: Genel Bakışı. Klimik Dergisi 2006;19(3):87-97.

19. Kostakoğlu U, Öztürk $U$, Durgun $M$, et al. Testis tümörüyle karışan brucella orşiti. Klimik Dergisi 2013;26(1):34-6.

20. Yıldırım ME, Yanaral F, Karabel D, et al. Unutulmakta olan bir 
epididimoorşit sebebi olarak brusella: 34 hastalık retrospektif çalışma. Yeni Tıp Dergisi 2013;30(1):16-8.

21. Patel PJ, Kolawole TM, Sharma N, et al. Sonographic findings in scrotal brucellosis. J Clin Ultrasound 1988;16:483-6.

22. Colmenero JD, Munoz-Roca NL, Bermudez P, et al. Clinical findings, diagnosticapproach, and outcome of brucella melitensis epididymo- orchitis. Diagn Microbiol Infect Dis 2007;57:367-72.
23. Demir T, Orhan B. Seroprevalence of brusellosis in Kirsehir province and significance of serological and biochemical tests in the diagnosis of brucellosis. Selçuk Tıp Derg 2012;28(3):173-7.

24. TC Sağlık Bakanlığı, Bulaşıcı hastalıkların ihbarı ve bildirim sistemi, standart tanı, sürveyans ve laboratuvar rehberi. Ankara 2004; p:40. 